\title{
Intramolecular cycloaddition reaction of bromo and nitro substituted furanyl amides
}

\author{
Albert Padwa*, Kenneth R. Crawford, and Christopher S. Straub \\ Department of Chemistry, Emory University, Atlanta, GA 30322 \\ E-mail: chemap@emory.edu
}

\section{Dedicated to Waldemar Adam on the occasion of his 70th anniversary}

\begin{abstract}
The intramolecular Diels-Alder reaction (IMDAF) of an $N$-alkenyl substituted furanyl amide was investigated. Upon thermolysis at $80-110{ }^{\circ} \mathrm{C}$, a smooth IMDAF reaction occurred to provide a stable aza-7-oxabicyclo[2.2.1] heptane cycloadduct in high yield. The intramolecular cyclization of the related 5-bromo substituted furanyl amide was found to proceed at a much faster rate and in higher yield than the unsubstituted variant. The rate enhancement observed by incorporating a bromine in the 5-position of the furan ring appears to be general. The origin of the increased rate of cycloaddition for the 5-bromo substituted furan when compared to the unsubstituted example can be attributed to an increase in reaction exothermicity; this both decreases the activation enthalpy, and increases the barrier to retrocycloaddition. Bromine substitution on furan also increases reactant energy and stabilizes the product due to the preference of the electronegative bromine atom to be attached to a more highly alkylated, and therefore more electropositive framework. An unusual isomerization-cyclization reaction of a 5-nitro substituted furanyl amide was also found to occur under microwave conditions and provided a 1,4-dihydro- $2 \mathrm{H}$ benzo[4.5]furo[2,3-c]pyridin-3-one derivative.
\end{abstract}

Keywords: Furans, intramolecular, [4+2], Diels-Alder, cycloaddition, synthesis

\section{Introduction}

The rhodium(II)-catalyzed reaction of $\alpha$-diazo ketones bearing tethered alkyne units represents a powerful method for the construction of a variety of polycyclic skeletons. ${ }^{1}$ Exposure of the starting $\alpha$-diazo ketone to a rhodium(II) catalyst results in cyclization of the $\alpha$-keto carbenoid to an intermediate in which carbene-like reactivity has been transferred to one of the original alkyne carbon atoms. A neighboring functional present on the backbone then traps the cyclized intermediate via known carbenoid chemistry to give various products. ${ }^{2}$ During the course of our studies in this area, we reported on a novel construction of bicyclic furans by coupling a metal 
carbenoid cyclization onto a tethered alkyne with an electrocyclization reaction (Scheme 1). ${ }^{3}$ Transformations of this type are of considerable synthetic utility, since the vast majority of furano-sesquiterpenes are functionalized at the $C_{3}$ and $C_{4}$ position of the furan ring. ${ }^{4,5}$ Use of an ester group $\left(\mathrm{R}_{1}=\mathrm{OEt}\right)$ also allows for transformation of $\mathbf{2}$ to the corresponding butenolide system 3. Formation of five-membered rings by $6 \pi$-electrocyclization is a well-precedented process in heterocyclic chemistry. ${ }^{6-10}$ Several different synthetic approaches to alkenone carbenes have been developed over the years, producing intermediates that display common trends in their reactivity. ${ }^{11-17}$ The utility of this cyclization approach to ring construction would be significantly expanded if the resulting bicyclic furan 2 was to undergo a subsequent [4+2]-cycloaddition, since a cyclohexane annulation would then result (i.e., $\mathbf{2} \rightarrow \mathbf{4} \rightarrow \mathbf{5}$ ). As part of our broader interest in using furan-cycloaddition products for the synthesis of natural products, ${ }^{18,19}$ we examined the strategic incorporation of several functional groups into the furan moiety that could be leveraged for the further transformation.
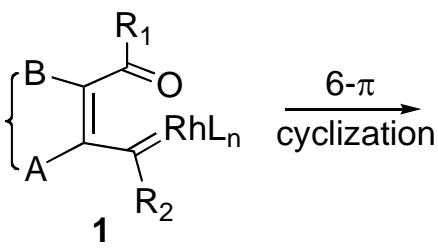
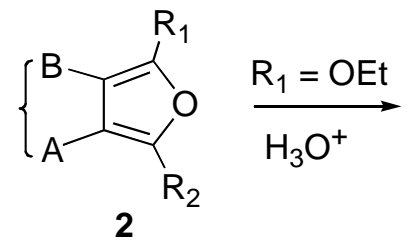

$\mid \begin{aligned} & X=Y \\ & {[4+2]}\end{aligned}$

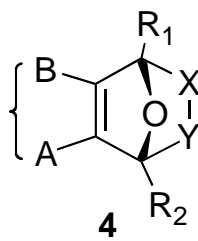

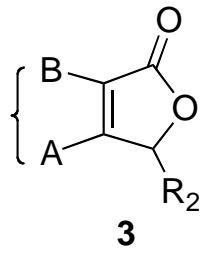

3

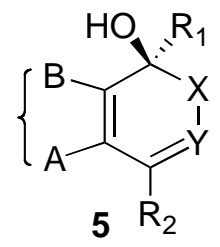

\section{Scheme 1}

\section{Results and Discussion}

Our initial studies focused on an intramolecular variation of the Rh(II)-catalyzed cyclization/Diels-Alder cycloaddition sequence of a propargyl diazo malonic ester system. The reaction of diazo ester 6 with $\mathrm{Rh}_{2}(\mathrm{OAc})_{4}$ followed by protiodesilylation with TBAF produced furan 7 in good yield. Heating a sample of 7 at $145{ }^{\circ} \mathrm{C}$ in xylene furnished indacene dione 10 (36\%) and the dienol- substituted lactone 11 (63\%) (Scheme 2). These products are presumably derived by an initial IMDAF reaction (intramolecular Diels-Alder of furan) ${ }^{20}$ followed by 
opening of the oxybridge of cycloadduct 8 to give oxonium ion $\mathbf{9}$. A subsequent loss of a proton from either of the two available positions nicely accounts for the products formed.

In contrast to this result, thermolysis of the related bromofuran 13, derived from the $\mathrm{Rh}(\mathrm{II})$ catalyzed reaction of diazo ester 12, gave the unusual rearranged bromide $\mathbf{1 7}$ as the major product in 43\% yield (Scheme 3). Presumably, 17 arises from an initial intramolecular DielsAlder reaction of furan $\mathbf{1 3}$ to give oxabicycle 14. Fragmentation of the oxabridge results in a zwitterionic intermediate 15, which can ketonize with the expulsion of a bromide ion, producing oxonium ion 16. The ejected bromide ion then attacks the oxonium ion at the adjacent methylene position, leading to the observed product.

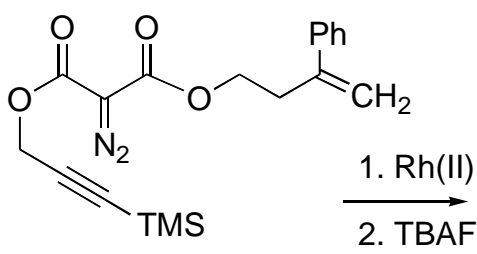

6

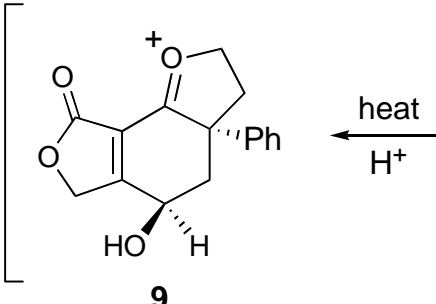

9

$\downarrow-\mathrm{H}^{+}$<smiles>O=C1OC=C2C1=C1OCCC1(c1ccccc1)C[C@H]2O</smiles>

10<smiles>C=C(CCOc1occ2c1C(=O)OC2)c1ccccc1</smiles>

7<smiles>[3H][Mg][3H]</smiles><smiles>CCC12CC(C)(CO1)C1=C2C(=O)OC1</smiles><smiles>O=C1OCC2C(=O)CC3(c4ccccc4)CCOC3=C12</smiles>

11

\section{Scheme 2}


<smiles>C=C(P)CCOc1oc(Br)c2c1C(=O)OC2(C)C</smiles>

13

$b$<smiles>CC1(Br)C[C@]([O-])(c2ccccc2)C2=C1C(C)(C)OC2=O</smiles>

15

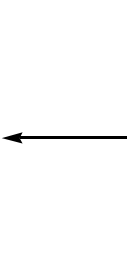<smiles>CC12CCC(Br)(C1)C1=C2C(=O)OC1(C)C</smiles>

14<smiles>CC1(C)OC(=O)C2=C1C(=O)CC(CCBr)(c1ccccc1)C2=O</smiles>

17

Reagents: (a) $\mathrm{Rh}_{2}(\mathrm{OAc})_{4}$, $\mathrm{PhH}$, heat; (b) xylene, $145^{\circ} \mathrm{C}, 43 \%$.

\section{Scheme 3}

Intrigued by these results and considering the importance of 7-oxabicyclo [2.2.1]heptanes as valuable synthetic intermediates, we decided to examine some related systems that could provide polyfunctional oxabicycles. 5-Bromo-2-furoyl amide 19 was prepared by $N$-allylation of the secondary amide 18 under phase transfer conditions (Scheme 4). Heating a sample of furan 19 at $110{ }^{\circ} \mathrm{C}$ for $90 \mathrm{~min}$ provided the stable oxatricycle $\mathbf{2 0}$ as a single diastereomer. The stereochemistry of $\mathbf{2 0}$ is consistent with preferred exo-orientation of the tether in the Diels-Alder cycloaddition reaction and is analogous with that reported by others for related furanyl systems possessing short tethers. ${ }^{21}$ In marked contrast to this finding, it was necessary to heat the unsubstituted amidofuran $(\mathrm{X}=\mathrm{H})$ for one week at $110{ }^{\circ} \mathrm{C}$ in order to complete the cycloaddition of 22 to 23 . 


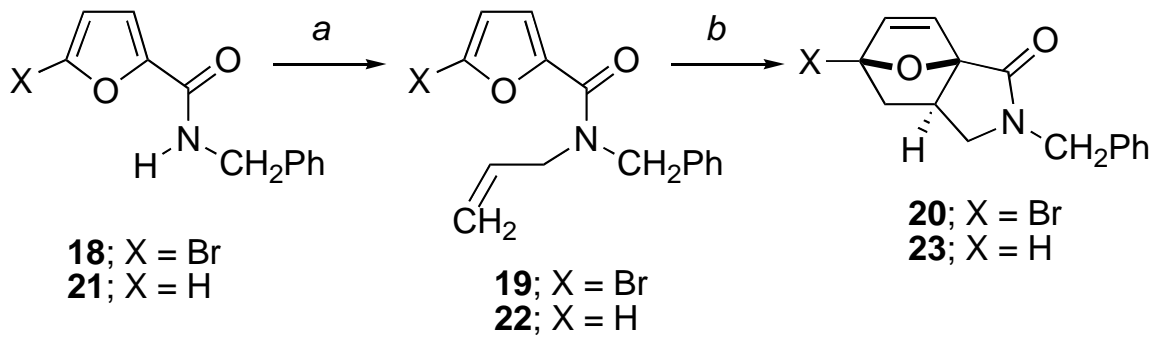

Reagents: (a) $\mathrm{NaOH}, \mathrm{K}_{2} \mathrm{CO}_{3}, n-\mathrm{Bu}_{4} \mathrm{NHSO}_{4}$, allyl bromide (b) $\mathrm{PhCH}_{3}$, heat.

\section{Scheme 4}

The rate enhancement observed by incorporating a bromine or another halogen group at the 5 -position appears to be general. ${ }^{22}$ The origin of the increased bimolecular cycloaddition rate for the 5-bromo-substituted furans was recently investigated by Houk and Pieniazek using quantum mechanical calculations. ${ }^{23}$ The origin of the increased rate of cycloaddition for the 5-bromo substituted furan when compared to the unsubstituted example can be attributed to an increase in reaction exothermicity; this both decreases the activation enthalpy, and increases the barrier to retrocycloaddition. Bromine substitution on furan also increases reactant energy and stabilizes the product due to the preference of the electronegative bromine atom to be attached to a more highly alkylated, and therefore more electropositive framework.

The remarkable enhancement in the rate of the cycloaddition involving bromo furans, combined with our recent success with cycloadditions across heteroaromatic $\pi$-systems, ${ }^{24}$ also prompted us to examine the IMDAF reaction using the electron withdrawing nitro group, rather than the bromo-substituent. Accordingly, we prepared the 5-nitro-furan variant $\mathbf{2 4}$ and found that when nitrofuran 24 was exposed to microwave irradiation for $15 \mathrm{~min}$ in $\mathrm{N}$-methyl-2pyrrolidinone (NMP), furan 25 was isolated as the major product (Scheme 5). Compound 25 was unequivocally assigned by a single crystal X-ray analysis (Figure 1).<smiles>COc1cccc2c(CN(C(=O)Cn3cccc3[N+](=O)[O-])C(C)(C)C)coc12</smiles>

\section{Scheme 5}




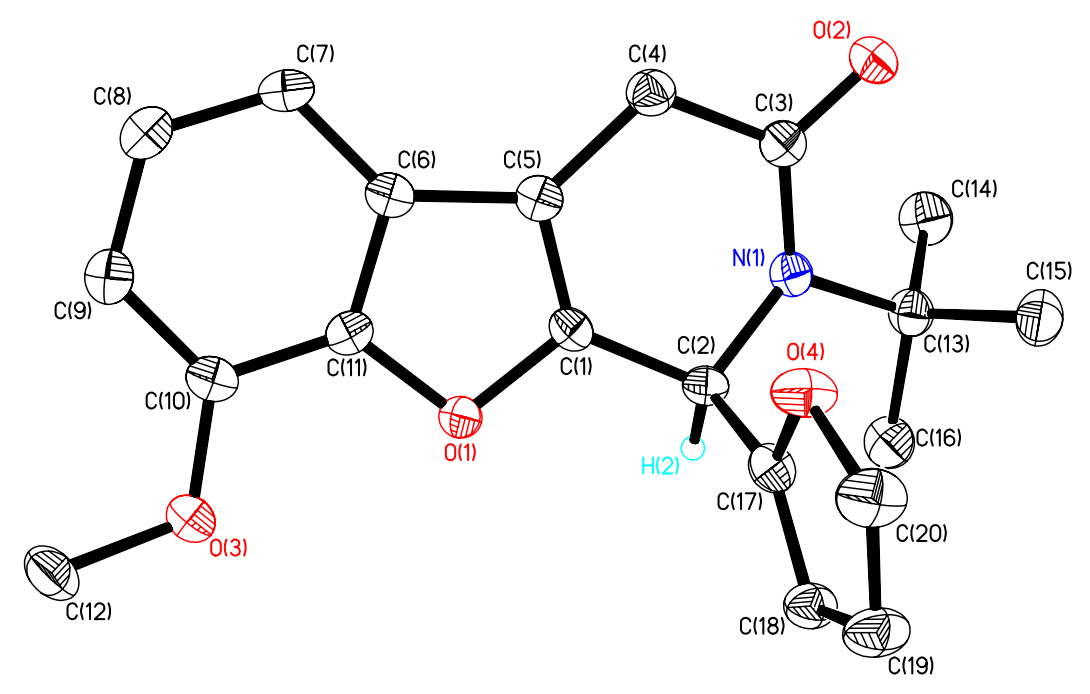

Figure 1. Ortep drawing of compound 25.

A more detailed study of the reaction showed that catalytic amounts of 2,6-lutidine enhanced the formation of 25, suggesting a mechanism involving a base catalyzed tautomerization of the furfuryl moiety to give intermediate $\mathbf{2 6}$ as a transient species. The lone pair of electrons on the amide nitrogen facilitates the loss of the nitro group to furnish acyl iminium ion $\mathbf{2 7}$ which then undergoes a subsequent cyclization with the adjacent benzofuran as shown in Scheme 6.<smiles>COc1cccc2c(CC(=O)N(Cc3ccc([N+](=O)[O-])o3)C(C)(C)C)coc12</smiles><smiles>COc1cccc2c(CC(=O)N(CCC3CC4CCC3CC4)CC3CCCCC3)coc12</smiles><smiles></smiles><smiles>COc1cccc2c3c(oc12)C(c1ccco1)N(C(C)(C)C)C(=O)C3</smiles><smiles>CCCCC(=O)N(/C=C/c1ccco1)C(=O)Cc1coc2c(OC)cccc12</smiles>

25

\section{Scheme 6}


In conclusion, the results presented herein demonstrate the versatility of the intramolecular [4+2]-cycloaddition reaction of substituted furans. Different rearrangement pathways of the resulting oxabicyclo adducts become available depending on the nature of the substituent group attached to the furan. We are currently investigating application of the methodology outlined here toward the synthesis of several alkaloid natural products.

\section{Experimental Section}

2-Diazo-malonic acid 3-bromo-1,1-dimethyl-prop-2-ynyl-3-phenyl-but-3-enyl ester (12). To a solution containing $4.2 \mathrm{mmol}$ of malonic acid mono-(3-bromo-1,1-dimethyl-prop-2-ynyl) ester $^{19}$ in $25 \mathrm{~mL}$ of $\mathrm{CH}_{2} \mathrm{Cl}_{2}$ at $0{ }^{\circ} \mathrm{C}$ under $\mathrm{Ar}$ was added 0.4 mmol of DMAP, 8.3 mmol of 3phenyl-3-buten-1-ol and $4.6 \mathrm{mmol}$ of 1,3-dicyclo-hexylcarbodiimide. The reaction mixture was allowed to stir at room temperature for $3 \mathrm{~h}$. The resulting suspension was filtered, the filtrate concentrated under reduced pressure and the crude residue was subjected to silica gel chromatography to give malonic acid 3-bromo-1,1-dimethyl-prop-2-ynyl-3-phenyl-but-3-enyl ester (97\%) as a light yellow oil; IR (neat) 2117, 1755, 1736, 1254, and $1123 \mathrm{~cm}^{-1}$; ${ }^{1} \mathrm{H}-\mathrm{NMR}$ $\left(400 \mathrm{MHz}, \mathrm{CDCl}_{3}\right) \delta 1.68(\mathrm{~s}, 6 \mathrm{H}), 2.87(\mathrm{dt}, 2 \mathrm{H}, J=7.2$ and $1.2 \mathrm{~Hz}), 3.30(\mathrm{~s}, 2 \mathrm{H}), 4.26(\mathrm{t}, 2 \mathrm{H}, J=$ $7.2 \mathrm{~Hz}), 5.15(\mathrm{dd}, 1 \mathrm{H}, J=1.2$ and $1.2 \mathrm{~Hz}), 5.39(\mathrm{~d}, 1 \mathrm{H}, J=1.2 \mathrm{~Hz})$, and 7.26-7.42 $(\mathrm{m}, 5 \mathrm{H})$; ${ }^{13} \mathrm{C}-$ NMR (100 MHz, $\left.\mathrm{CDCl}_{3}\right)$ d 28.8, 34.4, 42.4, 45.9, 64.3, 74.2, 76.9, 114.8, 126.2, 127.9, 128.7, 140.5, 144.1,164.8, and 166.6; HRMS Calcd. for $\mathrm{C}_{18} \mathrm{H}_{19} \mathrm{BrO}_{4}$ : 378.0467. Found: 378.0462.

To a solution containing $2.1 \mathrm{mmol}$ of the above malonic acid ester and $3.1 \mathrm{mmol}$ of 4 nitrobenzenesulfonyl azide in $20 \mathrm{~mL}$ of $\mathrm{CH}_{2} \mathrm{Cl}_{2}$ at $0{ }^{\circ} \mathrm{C}$ under $\mathrm{Ar}$ was added $6.7 \mathrm{mmol}$ of triethyl amine. After stirring the solution for $12 \mathrm{~h}$, the solvent was removed to give diazo ester 12 (95\%) as a yellow oil; IR (neat) 2203, 2138, 1758, 1736, 1695, and $1328 \mathrm{~cm}^{-1} ;{ }^{1} \mathrm{H}-\mathrm{NMR}$ (400 MHz, $\left.\mathrm{CDCl}_{3}\right) \mathrm{d} 1.72(\mathrm{~s}, 6 \mathrm{H}), 2.90(\mathrm{dt}, 2 \mathrm{H}, J=6.8$ and $0.8 \mathrm{~Hz}), 4.34(\mathrm{t}, 2 \mathrm{H}, J=6.8 \mathrm{~Hz}), 5.14(\mathrm{dd}, 1 \mathrm{H}, J$ $=0.8$ and $0.8 \mathrm{~Hz}), 5.38(\mathrm{~d}, 1 \mathrm{H}, J=0.8 \mathrm{~Hz})$, and 7.27-7.42 $(\mathrm{m}, 5 \mathrm{H}) ;{ }^{13} \mathrm{C}-\mathrm{NMR}\left(100 \mathrm{MHz}, \mathrm{CDCl}_{3}\right)$ d 29.2, 34.7, 46.3, 64.4, 74.8, 80.3, 115.0, 126.2, 127.9, 128.7, 140.4, 144.2, 159.2, and 160.9.

Diazo ester 12 was used in the next step without further purification.

6-(2-Bromo-ethyl)-3,3-dimethyl-6-phenyl-5,6-dihydro-3H-isobenzofuran-1,4,7-trione (17). To a solution of $1.6 \mathrm{~g}(0.4 \mathrm{mmol})$ of diazo ester $12 \mathrm{in} 5 \mathrm{~mL}$ of dry benzene at $80{ }^{\circ} \mathrm{C}$ was added 5 $\mathrm{mg}$ of $\mathrm{Rh}_{2}(\mathrm{OAc})_{4}$. The reaction mixture was heated at $80{ }^{\circ} \mathrm{C}$ for $15 \mathrm{~min}$. The solvent was removed under reduced pressure to give furan $\mathbf{1 3}$ as a clear oil which was used in the next step without further purification; 1H-NMR (400 MHz, CDCl3) d $1.60(\mathrm{~s}, 6 \mathrm{H}), 3.00(\mathrm{t}, 2 \mathrm{H}, J=6.0$ $\mathrm{Hz}), 4.50(\mathrm{t}, 2 \mathrm{H}, J=6.0 \mathrm{~Hz}), 5.20(\mathrm{~s}, 1 \mathrm{H}), 5.43(\mathrm{~s}, 1 \mathrm{H})$, and 7.26-7.42 (m, 5H).

Furan 13 was taken up in xylene, placed in a sealed tube, the tube was sealed and the mixture was heated at $145^{\circ} \mathrm{C}$ for $15 \mathrm{~h}$. The solution was concentrated under reduced pressure, and the residue was subjected to silica gel chromatography to give $0.07 \mathrm{~g}(43 \%)$ of the titled compound 17 as a pale yellow oil; IR (neat) 1780, 1796, 1446, 1390, and $1300 \mathrm{~cm}^{-1} ;{ }^{1} \mathrm{H}-\mathrm{NMR}$ (400 MHz, $\left.\mathrm{CDCl}_{3}\right) \mathrm{d} 1.31(\mathrm{~s}, 3 \mathrm{H}), 1.74(\mathrm{~s}, 3 \mathrm{H}), 2.49(\mathrm{ddd}, 1 \mathrm{H}, J=14.4,10.4$ and $6.0 \mathrm{~Hz}), 2.73(\mathrm{ddd}, 1 \mathrm{H}, J=$ 
16.0, 10.4 and $6.0 \mathrm{~Hz}), 3.08-3.19(\mathrm{~m}, 2 \mathrm{H}), 3.27(\mathrm{~d}, 1 \mathrm{H}, J=16.8 \mathrm{~Hz}), 3.72(\mathrm{~d}, 1 \mathrm{H}, J=16.8 \mathrm{~Hz})$, 7.12-7.15 (m, 2H) and 7.32-7.40 (m, 3H); ${ }^{13} \mathrm{C}-\mathrm{NMR}\left(100 \mathrm{MHz}, \mathrm{CDCl}_{3}\right) \mathrm{d}$ 23.9, 25.7, 26.6, 41.0, 47.8, 60.1, 84.2, 126.0, 129.3, 129.5, 130.3, 136.0, 164.5, 168.5, 188.8, and 194.2; Anal. Calcd. for $\mathrm{C}_{18} \mathrm{H}_{17} \mathrm{BrO}_{4}$ : C, 57.31; H, 4.54. Found: C, 57.04; H, 4.26.

5-Bromo-furan-2-carboxylic Acid Benzylamide (18). To a solution of 5-bromo-2-furoic acid (10 g, $52 \mathrm{mmol})$ in $\mathrm{CH}_{2} \mathrm{Cl}_{2}(65 \mathrm{~mL})$ at $0{ }^{\circ} \mathrm{C}$ was added $(\mathrm{COCl})_{2}(6.8 \mathrm{~mL}, 79 \mathrm{mmol})$ and DMF $(50$ $\mu \mathrm{L})$. The flask was fitted with a drying tube containing $\mathrm{CaSO}_{4}$ and the resulting solution was warmed to $\mathrm{rt}$ for $1.5 \mathrm{~h}$. Concentration under reduced pressure afforded the crude acid chloride as a yellow solid that was used directly in the next step without further purification. A solution of this acid chloride in THF $(20 \mathrm{~mL})$ was added slowly to solution of benzylamine $(6.2 \mathrm{~mL}, 57$ $\mathrm{mmol})$ and $\mathrm{Et}_{3} \mathrm{~N}(15 \mathrm{~mL}, 100 \mathrm{mmol})$ in $\mathrm{THF}(20 \mathrm{~mL})$ at $0{ }^{\circ} \mathrm{C}$. The solution was warmed to $\mathrm{rt}$ over $1 \mathrm{~h}$ and then $\mathrm{H}_{2} \mathrm{O}$ was added. The layers were separated and the aqueous layer was extracted with ether. The combined organic layer was dried $\left(\mathrm{MgSO}_{4}\right)$, filtered, and concentrated under reduced pressure. The yellow oil obtained was subjected to flash silica gel chromatography to give furanyl amide 18 (15 g, 100\%) as a white solid. All of its spectroscopic properties were identical to those reported previously. ${ }^{25}$

5-Bromo-furan-2-carboxylic Acid Allyl-benzylamide (19). A mixture of furan 18 (1.0 g, 3.6 mmol), powdered $\mathrm{NaOH}(0.6 \mathrm{~g}, 14 \mathrm{mmol}), \mathrm{K}_{2} \mathrm{CO}_{3}(0.5 \mathrm{~g}, 3.6 \mathrm{mmol})$, and $\left(n-\mathrm{Bu}_{4}\right) \mathrm{NHSO}_{4}(0.01$ $\mathrm{g}, 0.01 \mathrm{mmol})$ in benzene $(20 \mathrm{~mL})$ was stirred for $1 \mathrm{~h}$ at $\mathrm{rt}$. Allyl bromide $(0.6 \mathrm{~mL}, 7.2 \mathrm{mmol})$ was added, and the reaction mixture was stirred at $\mathrm{rt}$ for $22 \mathrm{~h}$. The mixture was diluted with water and the layers were separated. The aqueous layer was extracted with EtOAc, and the combined organic layers were dried $\left(\mathrm{MgSO}_{4}\right)$ and concentrated under reduced pressure. The resulting crude oil was subjected to flash silica gel chromatography to give $1.1 \mathrm{~g}(99 \%)$ of 19 as a colorless oil; IR (neat) 1711, 1624, 1572, 1478, 1414, 1261, and $1013 \mathrm{~cm}^{-1}$; ${ }^{1} \mathrm{H}-\mathrm{NMR}(400 \mathrm{~Hz}$, $\left.\mathrm{CDCl}_{3}\right)$ d 4.08 (brs, 2H), 4.59-4.88 (m, 2H), 5.08-5.35 (m, 2H), 5.79-5.95 (m, 1H), 6.39 (brs, $1 \mathrm{H}), 6.83-7.10(\mathrm{~m}, 1 \mathrm{H})$, and 7.16-7.45 (m, 5H); ${ }^{13} \mathrm{C}-\mathrm{NMR}\left(100 \mathrm{~Hz}, \mathrm{CDCl}_{3}\right) \mathrm{d}$ 48.8, 49.7, 113.2 , 117.8, 118.7, 124.5, 127.5, 128.6, 132.9 (br), 134.2, 136.7, 149.2, and 159.1; HRMS Calcd. for $\mathrm{C}_{15} \mathrm{H}_{14} \mathrm{BrNO}_{2}: 319.0208$. Found: 319.0208 .

3-Benzyl-7-bromo-10-oxa-3-aza-tricyclo[5.2.1.01,5]dec-8-en-2-one (20). A solution of furan $19(0.2 \mathrm{~g}, 0.66 \mathrm{mmol})$ in toluene $(7 \mathrm{~mL})$ was heated at $110{ }^{\circ} \mathrm{C}$ for $1.5 \mathrm{~h}$. The mixture was concentrated under reduced pressure and the crude oil was subjected to flash silica gel chromatography to give $\mathbf{2 0}(0.21 \mathrm{~g}, 99 \%)$ as a white solid, mp $120-121^{\circ} \mathrm{C}$; IR (film) 1702,1485 , 1435, and $1283 \mathrm{~cm}^{-1}$; ${ }^{1} \mathrm{H}-\mathrm{NMR}\left(300 \mathrm{MHz}, \mathrm{CDCl}_{3}\right) \mathrm{d}$ 2.13-2.25 (m, 2H), 2.33-2.42 (m, 1H), 3.26 $(\mathrm{dd}, 1 \mathrm{H}, J=9.9$ and $8.4 \mathrm{~Hz}), 3.47(\mathrm{dd}, 1 \mathrm{H}, J=9.9$ and $8.4 \mathrm{~Hz}), 4.46(\mathrm{~d}, 1 \mathrm{H}, J=15 \mathrm{~Hz}), 4.57$ (d, $1 \mathrm{H}, J=15 \mathrm{~Hz}), 6.50(\mathrm{~d}, 1 \mathrm{H}, J=5.4 \mathrm{~Hz}), 6.66(\mathrm{~d}, 1 \mathrm{H}, J=5.4 \mathrm{~Hz})$, and $7.24-7.38(\mathrm{~m}, 5 \mathrm{H}) ;{ }^{13} \mathrm{C}-$ NMR (75 MHz, $\left.\mathrm{CDCl}_{3}\right)$ d 42.1, 42.9, 47.3, 51.5, 90.8, 90.9, 128.1, 128.3, 129.1, 134.5, 135.7, 141.5, and 166.1; Anal. Calcd. for $\mathrm{C}_{15} \mathrm{H}_{14} \mathrm{BrNO}_{2}$ : C, 56.27; H, 4.41; N, 4.37. Found: C, 56.19; H, $4.20 ; \mathrm{N}, 4.16$. 
Furan-2-carboxylic Acid Allyl-benzylamide (22). A mixture of furan-2-carboxylic acid benzylamide (21) ${ }^{26}(0.72 \mathrm{~g}, 3.6 \mathrm{mmol})$ of powdered $\mathrm{NaOH}(0.6 \mathrm{~g}, 14 \mathrm{mmol}), \mathrm{K}_{2} \mathrm{CO}_{3}(0.5 \mathrm{~g}, 3.6$ $\mathrm{mmol})$, and $\left(n-\mathrm{Bu}_{4}\right) \mathrm{NHSO}_{4}(0.02 \mathrm{~g}, 0.06 \mathrm{mmol})$ in toluene $(20 \mathrm{~mL})$ was stirred for $1 \mathrm{~h}$ at $\mathrm{rt}$. Allyl bromide $(0.86 \mathrm{~g}, 7.1 \mathrm{mmol})$ was added, and the reaction mixture was heated at $110{ }^{\circ} \mathrm{C}$ for 48 h. The mixture was cooled, diluted with water, and extracted with EtOAc. The combined organic layer was dried $\left(\mathrm{MgSO}_{4}\right)$ and concentrated under reduced pressure. The crude oil was subjected to flash silica gel chromatography to give $0.34 \mathrm{~g} \mathrm{(40 \% )} \mathrm{of} 22$ as a yellow oil; IR (neat) 1633, 1574, 1487, 1177, and $1015 \mathrm{~cm}^{-1}$; ${ }^{1} \mathrm{H}-\mathrm{NMR}$ (400 Hz, CDCl3) d 4.07 (brs, 2H), 4.74 (brs, $2 \mathrm{H}), 5.05-5.35(\mathrm{~m}, 2 \mathrm{H}), 5.76-5.98(\mathrm{~m}, 1 \mathrm{H}), 6.43(\mathrm{~s}, 1 \mathrm{H}), 7.02$ (brs, $1 \mathrm{H}), 7.16-7.40(\mathrm{~m}, 5 \mathrm{H})$, and 7.44 (s, 1H); ${ }^{13} \mathrm{C}-\mathrm{NMR}\left(100 \mathrm{~Hz}, \mathrm{CDCl}_{3}\right) \mathrm{d} 48.5,49.5,106.3,111.1,116.2,117.6,127.3,128.5$, 133.2, 136.8, 143.9, 147.6, and 160.2; Anal. Calcd. for $\mathrm{C}_{15} \mathrm{H}_{15} \mathrm{NO}_{2}$ : C, 74.67; H, 6.27; N, 5.80. Found: C, 74.49; H, 6.08; N, 5.63.

This reaction also produced $0.42 \mathrm{~g}(48 \%)$ of cycloadduct 23.

3-Benzyl-10-oxa-3-aza-tricyclo[5.2.1.01,5]dec-8-en-2-one (23). A 0.16 g sample of 22 (0.66 $\mathrm{mmol})$ in toluene $(7 \mathrm{~mL})$ was heated at $125^{\circ} \mathrm{C}$ for 7 days. The mixture was concentrated under reduced pressure, and the residue was subjected to flash silica gel chromatography to give $0.16 \mathrm{~g}$ (98\%) of 23 as a white solid: $\mathrm{mp} 140-141{ }^{\circ} \mathrm{C}$; IR (film) 1690, 1446, 1282, 1158 and $1020 \mathrm{~cm}^{-1}$; ${ }^{1} \mathrm{H}-\mathrm{NMR}\left(300 \mathrm{MHz}, \mathrm{CDCl}_{3}\right) \mathrm{d} 1.47(\mathrm{dd}, 1 \mathrm{H}, J=11.7$ and $7.5 \mathrm{~Hz}), 1.75-1.90(\mathrm{~m}, 1 \mathrm{H}), 2.21$ (ddd, $1 \mathrm{H}, J=16.1,8.1$ and $3.0 \mathrm{~Hz}), 3.11(\mathrm{dd}, 1 \mathrm{H}, J=9.5$ and $8.5 \mathrm{~Hz}), 3.40(\mathrm{dd}, 1 \mathrm{H}, J=9.5$ and 8.5 $\mathrm{Hz}), 4.48(\mathrm{~s}, 2 \mathrm{H}), 5.10-5.20(\mathrm{~m}, 1 \mathrm{H}), 6.37-6.45(\mathrm{~m}, 1 \mathrm{H}), 6.54-6.62(\mathrm{~m}, 1 \mathrm{H})$, and 7.16-7.35 (m, 5H); ${ }^{13} \mathrm{C}-\mathrm{NMR}\left(75 \mathrm{MHz}, \mathrm{CDCl}_{3}\right) \mathrm{d}$ 31.0, 38.7, 46.7, 51.4, 81.4, 91.8, 127.4, 127.8, 128.6, 133.0, 135.8, 137.1, and 168.1; Anal. Calcd. for $\mathrm{C}_{15} \mathrm{H}_{15} \mathrm{NO}_{2}$ : C, 74.67; H, 6.27; N, 5.81. Found: C, $74.51 ; \mathrm{H}, 6.11 ; \mathrm{N}, 5.74$.

$\mathrm{N}$-tert-Butyl-2-(7-methoxy-benzofuran-3-yl)- $\mathrm{N}$-(5-nitro-furan-2-ylmethyl)-acetamide (24). Following the procedure used for reductive amination as described by Abdel-Magid, ${ }^{27}$ 5-nitro-2furfural $(3.0 \mathrm{~g}, 21 \mathrm{mmol})$, tert-butylamine $(2.2 \mathrm{~mL}, 21 \mathrm{mmol})$, and $\mathrm{NaBH}(\mathrm{OAc})_{3}(6.8 \mathrm{~g}, 32$ $\mathrm{mmol})$, and dichloroethane $(72 \mathrm{~mL})$ gave tert-butyl-(5-nitro-furan-2-ylmethyl)amine as an orange solid that was used in the next step without any further purification; mp $25-26{ }^{\circ} \mathrm{C}$; IR (neat) 1593, 1529, 1356, 1229, and $739 \mathrm{~cm}^{-1}$; ${ }^{1} \mathrm{H}-\mathrm{NMR}\left(400 \mathrm{~Hz}, \mathrm{CDCl}_{3}\right) \mathrm{d} 1.16$ (s, 9H), 1.62 (brs, $1 \mathrm{H}), 3.82(\mathrm{~s}, 2 \mathrm{H}), 6.46(\mathrm{~d}, 1 \mathrm{H}, J=3.6 \mathrm{~Hz})$, and $7.24(\mathrm{~d}, 1 \mathrm{H}, J=3.6 \mathrm{~Hz},) ;{ }^{13} \mathrm{C}-\mathrm{NMR}(100$ $\mathrm{Hz}, \mathrm{CDCl}_{3}$ ) d 28.8, 40.1, 50.9, 109.9, 112.8 (br), and 159.5.

A mixture of (7-methoxy-benzofuran-3-yl)-acetic $\operatorname{acid}^{28}(0.21 \mathrm{~g}, 1.0 \mathrm{mmol}),(\mathrm{COCl})_{2}(0.26 \mathrm{~mL}$, $3.0 \mathrm{mmol})$, in $\mathrm{CH}_{2} \mathrm{Cl}_{2}(80 \mathrm{~mL})$ was treated with $\mathrm{DMF}(0.1 \mathrm{~mL})$. A drying tube $\left(\mathrm{CaSO}_{4}\right)$ was added, and the mixture was stirred for $3 \mathrm{~h}$. The mixture was then concentrated under reduced pressure to give the crude acid chloride. A cooled solution of the above amide (2.8 $\mathrm{g}, 12.1 \mathrm{mmol})$ and pyridine $(1.8 \mathrm{~mL}, 24.2 \mathrm{mmol})$ in $\mathrm{CH}_{2} \mathrm{Cl}_{2}(80 \mathrm{~mL})$ was added. After stirring for $1 \mathrm{~h}$ at $\mathrm{rt}$, the reaction mixture was subjected to aqueous workup, and the residue was chromatographed on a silica gel column to give the title compound $24(0.16 \mathrm{~g}, 41 \%)$ as a pale yellow solid: $\mathrm{mp} 140-142$ ${ }^{\circ} \mathrm{C}$; IR (film) 1654, 1629, 1625, 1497, and $1359 \mathrm{~cm}^{-1}$; ${ }^{1} \mathrm{H}-\mathrm{NMR}\left(300 \mathrm{MHz}, \mathrm{CDCl}_{3}\right) \mathrm{d} 1.48$ (s, 
9H), $3.75(\mathrm{~d}, 1 \mathrm{H}, J=1.2 \mathrm{~Hz}), 3.99(\mathrm{~s}, 3 \mathrm{H}), 4.65(\mathrm{~s}, 2 \mathrm{H}), 6.41(\mathrm{~d}, 1 \mathrm{H}, J=3.6 \mathrm{~Hz}), 6.82(\mathrm{dd}, 1 \mathrm{H}, J$ $=6.0,1.5 \mathrm{~Hz}), 7.05-7.20(\mathrm{~m}, 2 \mathrm{H}), 7.22-7.31(\mathrm{~m}, 1 \mathrm{H})$, and $7.55(\mathrm{~s}, 1 \mathrm{H}) ;{ }^{13} \mathrm{C}-\mathrm{NMR}(75 \mathrm{MHz}$, $\left.\mathrm{CDCl}_{3}\right) \mathrm{d} 28.7,32.5,42.9,56.1,58.5,106.8,110.2,111.9,112.3,114.5,123.5,129.2,142.4$, 144.5, 145.5, 156.4, and 170.7; Anal. Calcd. for $\mathrm{C}_{20} \mathrm{H}_{22} \mathrm{~N}_{2} \mathrm{O}_{6}: \mathrm{C}, 62.17$; H, 5.74; N, 7.25. Found: C, 62.30; H, 5.71; N, 5.65.

\section{2-tert-Butyl-1-furan-2-yl-8-methoxy-1,4-dihydro-2H-benzo[4,5]furo[2,3-c]pyridin-3-one} (25). A $10 \mathrm{~mL}$ glass microwave reaction vessel containing furanyl amide 24 (0.07 g, $0.18 \mathrm{mmol})$, dry 1-methyl-2-pyrrolidinone (NMP, $2 \mathrm{~mL}$ ) and a magnetic stir bar was sealed with a septum and irradiated for $15 \mathrm{~min}$ using a power of $300 \mathrm{~W}$ with continuous cooling (60 psi of compressed air). After cooling to $\mathrm{rt}$, the mixture was subjected to the normal aqueous workup, and the residue was purified by preparative silica gel chromatography to give $25(0.022 \mathrm{~g}, 36 \%)$ as a yellow solid: $\mathrm{mp} 164-166{ }^{\circ} \mathrm{C}$; IR (film) 1678, 1654, 1620, 1498, 1207, and $731 \mathrm{~cm}^{-1}$; ${ }^{1} \mathrm{H}-\mathrm{NMR}$ $\left(600 \mathrm{~Hz}, \mathrm{CDCl}_{3}\right) \mathrm{d} 1.44(\mathrm{~s}, 9 \mathrm{H}), 3.70(\mathrm{~d}, 1 \mathrm{H}, J=20.4 \mathrm{~Hz}), 3.98(\mathrm{dd}, 1 \mathrm{H}, J=20.4$ and $1.8 \mathrm{~Hz})$, $3.98(\mathrm{~s}, 3 \mathrm{H}), 6.04(\mathrm{~s}, 1 \mathrm{H}), 6.27-6.31(\mathrm{~m}, 1 \mathrm{H}), 6.33(\mathrm{~d}, 1 \mathrm{H}, J=3.6 \mathrm{~Hz}), 6.80(\mathrm{~d}, 1 \mathrm{H}, J=7.8 \mathrm{~Hz})$, $7.06(\mathrm{~d}, 1 \mathrm{H}, J=7.2 \mathrm{~Hz}), 7.17(\mathrm{t}, 1 \mathrm{H}, J=7.8 \mathrm{~Hz})$, and $7.30(\mathrm{~s}, 1 \mathrm{H}) ;{ }^{13} \mathrm{C}-\mathrm{NMR}\left(150 \mathrm{~Hz}, \mathrm{CDCl}_{3}\right) \mathrm{d}$ 28.3, 31.7, 50.7, 56.0, 58.9, 106.7, 107.7, 110.3, 110.5, 111.6, 123.9, 128.2, 142.6, 144.3, 145.4, 148.4, 152.0, and 170.0; Anal. Calcd. for $\mathrm{C}_{20} \mathrm{H}_{21} \mathrm{NO}_{4}$ : C, 70.78; H, 6.24; N, 4.13. Found: C, $70.63 ; \mathrm{H}, 6.13 ; \mathrm{N}, 4.06$.

\section{Acknowledgements}

We appreciate the financial support provided by the National Science Foundation (Grant No. CHE-0450779) and the National Institutes of Health (GM 059384) for generous support of this work. We thank our colleague, Dr. Kenneth Hardcastle, for his assistance with the X-ray crystallographic studies and the University Research Committee of Emory University for funds to acquire a microwave reactor.

\section{References}

1. (a) Padwa, A.; Krumpe, K. E.; Gareau, Y.; Chiacchio, U. J. Org. Chem. 1991, 56, 2523. (b) Padwa, A.; Xu, S. L. J. Am. Chem. Soc. 1992, 114, 5881. (c) Padwa, A.; Kassir, J. M.; Xu, S. L. J. Org. Chem. 1991, 56, 6971. (d) Baird, M. S.; Buxton, S. R; Whitley, J. S. Tetrahedron Lett. 1984, 25, 1509. (e) Padwa, A.; Fryxell, G. E.; Zhi, L. J. Org. Chem. 1988, 53, 2875. (f) Padwa, A.; Krumpe, K. E.; Zhi, L. Tetrahedron Lett. 1989, 30, 2633. (g) Padwa, A.; Chiacchio, U.; Garreau, Y.; Kassir, J. M.; Krumpe, K. E.; Schoffstall, A. M. J. Org. Chem. 1990, 55, 414. (h) Padwa, A.; Austin, J. A.; Xu, S. L. J. Org. Chem. 1992, 57, 1330. (i) Padwa, A.; Krumpe, K. E.; Kassir, J. M. J. Org. Chem. 1992, 57, 4940. (j) Padwa, A.; 
Austin, D. J.; Xu, S. L. Tetrahedron Lett. 1991, 32, 4103. (k) Padwa, A.; Chiacchio, U.; Fairfax, D. J.; Kassir, J. M.; Litrico, A.; Semones, M. A.; Xu, S. L. J. Org. Chem. 1993, 58, 6429. (1) Padwa, A.; Kassir, J. M.; Semones, M. A.; Weingarten, M. D. J. Org. Chem. 1995, 60, 53. (m) Padwa, A.; Austin, D. J.; Chiacchio, U.; Kassir, J. M.; Rescifina, A.; Xu, S. L. Tetrahedron Lett. 1991, 32, 5923.

2. For a mini-review see, Padwa, A. J. Organometallic Chem. 2001, 617, 3.

3. (a) Kinder, F. R.; Padwa, A. Tetrahedron Lett. 1990, 31, 6835. (b) Padwa, A.; Kinder, F. R. J. Org. Chem. 1993, 58, 21. (c) Padwa, A.; Straub, C. S. Org. Lett. 2000, 2, 2093.

4. (a) Rigby, J. H.; Wilson, J. Z. J. Org. Chem. 1987, 52, 34. (b) Rigby, J. H.; Senanayake, C. J. Am. Chem. Soc. 1987, 109, 3147.

5. Jacobi, P. A.; Selnick, H. G. J. Org. Chem. 1990, 55, 202.

6. Taylor, E. C.; Turchi, I. J. Chem. Rev. 1979, 79, 181.

7. Huisgen, R. Angew. Chem. Int. Ed. 1980, 19, 947.

8. Speckamp, W. N.; Veenstra, S. J.; Dijkink, J.; Fortgens, R. J. Am. Chem. Soc. 1981, 103, 4643.

9. Visser, G. W.; Verboom, W.; Benders, P. H.; Reinhoudt, D. N. J. Chem. Soc., Chem. Comm. 1982, 669.

10. Padwa, A.; Bakulev, V. A.; Kappe, C. O. Organic Synthesis: Theory and Applications, JAI Press, 1996; Vol. 3, pp149-229.

11. Padwa, A.; Akiba, M.; Chou, C. S.; Cohen, L. J. Org. Chem. 1982, 47, 183.

12. Eberbach, W.; Roser, J. Tetrahedron Lett. 1987, 28, 2685.

13. Hilderbrandt, K.; Debaerdemacker, T; Friedrichsen, W. Tetrahedron Lett. 1988, 29, 2045.

14. Hamaguchi, M.; Ibata, T. Chem. Lett. 1976, 287.

15. Maier, M. E.; Schoeffling, B. Chem. Ber. 1989, 122, 1081.

16. Davies, H. M. L.; Romines, K. R. Tetrahedron 1988, 44, 3343.

17. Padwa, A.; Straub, S. S. Org. Lett. 2000, 2, 2093.

18. Padwa, A.; Ginn, J. D.; Bur, S. K.; Eidell, C. K.; Lynch, S. M. J. Org. Chem. 2002, 64, 3412. 19. Padwa, A.; Straub, C. S. J. Org. Chem. 2003, 68, 227.

20. (a) Kappe, C. O.; Murphree, S. S.; Padwa, A. Tetrahedron 1997, 53, 14179. (b) Sternbach, D. D.; Rossana, D. M.; Onon, K. D. J. Org. Chem. 1984, 49, 3427. (c) Jung, M. E.; Gervay, J. J. Am. Chem. Soc. 1989, 111, 5469.

21. (a) Woo, S.; Keay, B. A. Tetrahedron: Asymmetry 1994, 5, 1411. (b) Rogers, C.; Keay, B. A. Tetrahedron Lett. 1991, 32, 6477. (c) Rogers, C.; Keay, B. A. Synlett 1991, 353. (d) Rogers, C.; Keay, B. A. Can. J. Chem. 1992, 70, 2929. (e) DeClercq, P. J.; Van Royen, L. A. Synth. Commun. 1979, 9, 771. (f) Van Royen, L. A.; Mijngher, R. ; DeClercq, P. J. Bull. Soc. Chim. Belg. 1984, 93, 1019. (g) Fischer, K.; Hunig, S. J. Org. Chem. 1987, 52, 564. (h) Padwa, A.; Brodney, M. A.; Satake, K.; Straub, C. S. J. Org. Chem. 1999, 64, 4617. (i) Crawford, R. K.; Bur, S. K.; Straub, C. S.; Padwa, A. Org. Lett. 2003, 5, 3337.

22. For a study of halo substituent effects in related IMDAF reactions, see: Klepo, Z.; Jakop, K. J. Heterocyclic Chem. 1987, 24, 1787. 
23. Pieniazek, S. N.; Houk, K. N. Angew. Chem. Int. Ed. 2006, 45, 1442. (b) Padwa, A.; Crawford, K. R.; Straub, C. S.; Pieniazek, S. N.; Houk, K. N. J. Or. Chem. 2006, 71, 5432.

24. (a) Lynch, S. M.; Bur, S. K.; Padwa, A. Org. Lett. 2002, 4, 4643. (b) J. M. Meija-Oneto; Padwa, A. Org. Lett. 2004, 6, 3241.

25. Rai, U. K.; Shanker, B.; Singh, S.; Rao, R. B. Indian J. Chem. Sect. B 1988, 27, 674.

26. (a) Knowles, H. S.; Parsons, A. F.; Pettifer, R. M.; Rickling, S. Tetrahedron 2000, 56, 979. (b) Dermer, O. C.; King, J. J. Org. Chem. 1943, 8, 168.

27. Abdel-Magid, A. F.; Carson, K. G.; Harris, B. D.; Maryanoff, C. A.; Shah, R. D. J. Org. Chem. 1996, 61, 3849.

28. Jung, M. E.; Albrecht, S. J. Org. Chem. 1988, 53, 423. 